\title{
EFL Secondary Teaching Practices in Blending Learning: A Case of Tabuk, Saudi Arabia
}

\author{
Reema Sultan Shaher Al-Saleh \\ Department of Curricula and Teaching Methods, \\ Faculty of Arts and Education, Tabuk University \\ E-mail: Reemalsaleh555@gmail.com
}

Received: August 15, 2017 Accepted: October 8, 2017 Published: October 10, 2017

doi:10.5296/elr.v3i2.11978ＵRL: http://doi.org/10.5296/elr.v3i2.11978

\begin{abstract}
This study investigated secondary stage teachers' Blended Learning (BL) current practices in Tabuk city. The qualitative data was collected from a random sample of 50 EFL teachers Interviews were conducted to examine EFL teachers'current practices of BL. The results of the interviews indicated that $84 \%$ of EFL teachers were neither familiar with the term BL nor had ever designed BL activities. $16 \%$ of the teachers stated that they were familiar with BL and provided examples of their current practices. The practices reflected their misconceptions about real implementation of BL method. Some of them thought that using simple technology like PowerPoint presentations with traditional textbook activities was a type of blending. None of the participants used language learning websites, mobile applications or online activities in their daily instruction. The teachers had no trouble identifying benefits of BL in English teaching but they lacked a clear vision of BL pedagogy, lesson/activity design and implementation. EFL teachers highlighted the need to provide them with training sessions, resources, capabilities and support for effective implementation.
\end{abstract}

Keywords: Blended learning, EFL teachers, Tabuk, Saudi Arabia

\section{Introduction}

The daily lifestyle of people including their living, work, entertainment, learning, and communication is significantly influenced by the Information and Communication Technology (ICT). Today's generation is extensively involved in using latest technologies, and favors its use in classrooms as well. E-learning is known as a common type of technology, which is integrated into educational learning. It provides online approach to various learning resources that can be accessed anytime and anywhere (Holmes \& Gardner, 2006). Blended learning provides a combination of traditional classroom skills along with online education. 
However, it connects the traditional physical classroom with the characteristics of virtual education (Finn \& Bucceri, 2004).

Alebaikan and Troudi (2010) have focused on the significance of blending learning in the universities of Saudi Arabia. The study has initially mentioned about certain challenges, which were faced by management during the implementation of blending learning processes. The foremost challenge was related with the adaptation of blended learning processes by the teachers and students because of traditional influence. It is also a fact that Saudi Ministry of Higher Education has mainly encouraged the utilization and implementation of information technology (IT) for the educational institutions and universities to attain their goals and objective effectively. Another significant challenge during the implementation of blended learning process was related to the increased growth of student population within the country. The study has mainly identified differential practical recommended, which are necessary to be implemented to facilitate the learning and educational processes effectively.

Al - Qahtani and Higgins (2013) have also investigated the association between blended learning and the students' achievements during the classroom learning in Umm Al-Qura University in Saudi Arabia. The findings have shown that there was a statistically significant difference present between the implementation of blended learning processes in terms of students' achievements. Therefore, the study has shown that information technology revolution has developed a significant expansion within the modern era.

Blended learning plays an important part in enhancing English language skills. The implication of blended learning has been proved effective in improving English language skills, but the willingness of teachers to adopt this technology in their teaching skills is lacking. Asiri et al. (2012) has identified certain barriers, which are mostly faced by the administration of universities during or after the application of blended learning processes or e-learning system.

\subsection{Aim of the Study}

The study has identified that adaptation of the system by faculty members is the most common barrier during the implementation of learning management system or e-learning system. The study has further identified that the attitudes of faculty members towards e-learning system, their beliefs towards the process, and their competence level while using blended learning approaches have mainly affected the smooth regulation of such processes. Therefore, this study has enlightened secondary teaching practices that need to be incorporated in blended learning. The technological advancements have provided various resources to optimize and advance the quality of teaching and learning. Therefore, blended learning should be encouraged among the EFL secondary teachers for development of different language skills. The results would be helpful for the teachers to adapt according to the technological advancement and global changes by creating different ways of teaching.

\subsection{Research Questions}

- Which type of instructions do teachers prefer? 


\section{Macrothink}

- Are you familiar with the term BL?

- If you are familiar with BL, have you ever designed BL lessons or activities?

- If you have designed some BL activities, give examples of some activities you have used?

- Why teachers have decided to use BL?

- What type of information and communication technology do you use in your EFL classes?

- What do EFL teachers need to integrate BL more effectively in teaching English?

- How often do you use technology in your teaching?

\section{Literature Review}

\subsection{Blended Learning}

Blended learning has the ability to create a motivated environment that blends the traditional strategies of learning with the advanced technologies. According to Neumier (2005), blended learning in a teaching and learning environment has been regarded as association between face to face and computer assisted learning (CAL). The blended learning is a combined association of various pedagogical approaches and technologies for a better and effective outcome (Mason \& Rennie, 2006). Means et al. (2013) has carried out a meta-analysis of the literature related to the effectiveness of online and blended learning. The study has indicated an increasing trend of blended learning within the academic processes. The findings have suggested that on average, the students have performed better in the online learning conditions as compared to the face-to-face instruction methods. Therefore, it has mainly identified blended learning as effective approach for providing idealistic education to the students.

\subsection{Types of Blended Learning}

Graham (2006) explained different types of blended learning, which include:

- Enabled Blended Learning: It uses different learning experiences through face to face interactions. It has been further identified that enabled blending usually focus on the resolution of different issues related to access for students. It provides the similar sort of opportunities or learning experience for the students, who have access related issues.

- Enhanced Blended Learning: This type of learning provides face to face learning environment along with supplementary online sources. Enhanced blending usually allows certain changes towards the pedagogy; however, it does not change anything related to the teaching styles. It can be said that additional resources and learning environment can be added to the online learning processes.

- Transformed Blended Learning: It utilizes combined approach of primary instructions and traditional face to face learning. Transforming blending process allows the radical 
transformation of the educational processes. It refers to the implementation of completely new model where learners can easily and actively get knowledge through dynamic interactions.

\subsection{Significance of Blended Learning}

Blended learning helps to generate better and improved learning outcomes (Lopez-Perez et al., 2011). It provides the students with greater understanding, competence, motivation, and satisfaction. Blended learning is significant as it improves pedagogy, teaching skills, easy access to knowledge, and revision of the learnt contents (Tayebinik \& Puteh, 2013). Bernard et al. (2014) has devoted to develop a proper understanding related with the effectiveness of blended learning in the higher educational processes. The findings have indicated that blended learning conditions are directly associated with the development of better skills and capabilities among the students in an effective way. Therefore, the study has mainly identified that blended learning system is significantly associated with the better performance of students.

\subsection{Teaching Practices and Blended Learning}

Teachers play a significant role in shaping the educational career of students through their effective teaching techniques. The success of incorporation of blended learning in the teaching practice is directly associated with the teachers' implementation of the latest approach of blended learning (Comas-Quinn, 2011). The involvement of teachers in blended learning environment has a positive influence on the learning abilities of the students. Poon (2013) has shown that blended learning is considered as a combination of face-to-face and online teaching approaches that will be effective for the students to improve their learning environment along with their study experiences, outcomes, and educational achievement. Grgurović (2010) and Aguilar and Aexandra (2012) emphasized that teachers' understanding of their roles and the media used in the blended environment create mixed models that can change students' learning outcomes and impact their acceptance of BL.

Higgins and Gomez (2014) and Allan (2007) described the technologies that can be used in the classroom such as interactive whiteboards, PowerPoint presentations, and audience response systems Virtual communication tools were also described such as discussion boards, chatting or conferencing e-lists, discussion groups, audio files, email, polling, news groups, questionnaires, web forms, and video conferencing. Social-networking software were further included such as phone calls, instant messaging, podcasts, video clips, social-networking sites, virtual worlds, Wikis, and weblogs; e-learning systems such as VLEs, group sites, and group collaboration software; and mobile learning through mobile phones, tablets, computers, and laptops. Ellis et al. (2006) suggested a similar range of tools for BL such as video and audio files, discussion boards, chats, and email. Ibrahim and Yusoff (2012) recommended YouTube, podcasts, and Wikis. To provide enhanced BL, teachers can combine several different media types (Joshi, 2012). 


\section{Macrothink}

\section{Methodology}

\subsection{Research Design}

The study has used qualitative method to investigate the teaching practices associated with blended learning. The rationale for using qualitative approach is to analyze diverse range of data, collected through semi-structured interviews, for assessing the basic aims of research.

\subsection{Study Sample}

50 secondary school teachers were recruited randomly from public secondary schools from four regions of Tabuk city. Salaria (2012) has defined the sample as the number of individuals, selected from a larger population with the purpose of obtaining information about this population as a whole. A good sample needs to be sufficient in number to reliably represent the population in its characteristics. In terms of the qualification of selected sample, $98 \%$ of teachers had Bachelor's degree; however, only 2\% had Master's degree. Similarly in terms of experience, $22 \%$ of the teachers had 5-9 years of experience within academic settings; $50 \%$ had 10-14 years of experience; $8 \%$ of teachers had 15-20 years of experience; and $10 \%$ of teachers had more than 20 years of work experience.

\subsection{Data Collection}

The data from the teachers was collected through semi-structured interviews to assess secondary teaching practices in blending learning. Interview can be defined as a conversation, which is done between the respondents and researcher to evaluate a specified range of objective (Gray, 2009). The research has extracted enormous benefits, related with the structured interviews from the participants. Some of the common benefits mainly include categorization of diverse range of information effectively, higher credibility along with better validity, better interpretation capability of teachers, and opportunity to resolve or clarify misunderstanding effectively. After developing the interview questions, an official permission letter was obtained from the Department of Education, Curriculum and Teaching Methods in Tabuk University.

\subsection{Analysis}

In accordance with the interview process, the first task was to explain the objectives of interview to the participants. 25 of the interviewees expressed interest and wanted to give more details about the obstacles they faced when applying BL and their needs. Finally, interview data were analyzed. In order to assess the reliability to structured interview questions, a pilot study was conducted on EFL secondary stage teachers. As a part of pilot study, the interview questions were distributed to 30 teachers. SPSS version 20.0 was used to analyze the obtained data. Table 1 represents reliability of interview questions: 
Table 1. Reliability of interview questions

\begin{tabular}{lll} 
Tool & Cronbach's alpha coefficient & Split-Half Method \\
\hline Interview & .7726 & .7690 \\
\hline
\end{tabular}

\section{Results and Discussion}

\subsection{Instruction Methods}

The interview session was comprised of 10 validated questions, which were asked from the participants.

Table 2. Types of Instruction Methods

\begin{tabular}{lllll}
\hline Types of instruction & $\mathrm{n}$ & $\%$ & $\mathrm{M}$ & $\mathrm{SD}$ \\
\hline Online Instruction & 1 & 2 & 2.94 & 0.314 \\
Face-to-face Instruction & 1 & 2 & & \\
Blend of Both Instruction Methods & 48 & 96 & \\
Total & 50 & 100 & \\
\hline
\end{tabular}

\subsection{Blended Learning}

It is evident from the findings that $96 \%$ of the teachers preferred to blend the two forms of teaching, and $2 \%$ preferred either online instruction or face-to-face instruction (Table 2). It implies that the teachers are willing to get benefits from blending procedure in terms of education and learning. Alammary et al. (2014) supported the arguments that the teachers are willing to opt blending procedure in learning for retrieving better outcomes.

Table 3. Familiarity with blended learning

\begin{tabular}{lllll}
\hline Response & $\mathrm{n}$ & $\%$ & $\mathrm{M}$ & $\mathrm{SD}$ \\
\hline Yes & 9 & 18 & 1.82 & 0.388 \\
No & 41 & 82 & & \\
Total & 50 & 100 & & \\
\hline
\end{tabular}

In response to this question, $82 \%$ of the teachers answered 'no', indicating a lack of familiarity, and 18\% answered in the favor of question (Table 3). Alebaikan and Troudi (2010) 


\section{Macrothink

have indicated that familiarity with 'BL' will be helpful for the teachers to understand the pedagogical theories to underpin blended courses. This percentage contradicts their responses to the first question. This means that they have misconceptions about the term BL. This result can be attributed to poor recognition of the term. Most EFL teachers have been integrating technology into instruction without using or fully understanding the term. Even those, who were familiar with the term, did not have enough formal knowledge to design BL lessons and activities. Moreover, the study has further mentioned that BL uses the strengths of both types of instruction to develop a successful teaching and learning environment.

Table 4. Extent of familiarity with blended learning

\begin{tabular}{lllll}
\hline Responses & $\mathrm{n}$ & $\%$ & $\mathrm{M}$ & $\mathrm{SD}$ \\
\hline Yes & 8 & 16 & 1.84 & .370 \\
No & 42 & 84 & & \\
Total & 50 & 100 & & \\
\hline
\end{tabular}

In response to this question, 4\% of the teachers answered 'no' indicating that they were unfamiliar with designing BL lessons or activities as compared to $16 \%$, who answered 'yes' (Table 4). This result may be attributed to a shortage of training sessions in applying BL methods and a general lack of awareness of BL.

Table 5. Designing of BL activities

\begin{tabular}{lll} 
Examples of Activities & $\mathrm{n}$ & $\%$ \\
\hline PowerPoint & 7 & 14 \\
Audio Files & 6 & 12 \\
Students' Textbooks & 6 & 12 \\
Videos & 5 & 10 \\
Worksheets & 5 & 10 \\
Interactive Whiteboard & 4 & 8 \\
Computer Games & 2 & 4 \\
Active Learning Strategies & 1 & 2 \\
\hline
\end{tabular}




\section{Macrothink}

Table 5 shows that $14 \%$ of teachers had designed BL activities. The provided examples included 14\% for using PowerPoint; $12 \%$ for using audio files and students' textbooks; $10 \%$ for using videos and worksheets; $8 \%$ for using interactive white boards; $4 \%$ for using computer games; and $2 \%$ for using active learning strategies. It has been opted from the outcomes that combination of traditional activities with simple technology may also explain teachers' misconceptions about blended learning. Bishop and Veliger (2013) have mentioned that the approach towards blended learning will be significant to ensure the better learning phase within the academic settings. The study has also indicated that BL activities should be promoted by management to comprehend the academic processes. Some teacher s added further clarification to interpret this point.

Teacher 1 stated that 'During 75\% of the class time, I use the interactive white board, audio, and video, and 25\% of the time, I use students'textbooks to read the lesson and answer the activities.'

Teacher 2 asserted ' $50 \%$ of the class time, I use power point and audio files and $50 \%$ of the class time I use worksheets and student's books.'

Teacher 3 said '25\% of class time I use power point and 75\% I use active learning strategies, students' books and worksheets.' Yet teacher 4 states 'I ask students to research some information about the lesson at home and on the next day I give them the face-to-face lesson.'

The researcher asked the teachers to give examples of BL activities to be sure if they have conceptual clarity or not. The examples they give do not reflect what exactly BL method refer to. This result reflects the effect of Kruger -Dunning' (1999) because people with very little knowledge of a subject tend to overestimate their ability to far greater than what it really is.

Table 6. Reasons for using BL

\begin{tabular}{lcccc}
\hline Teacher's Motivations & $\mathrm{n}$ & $\%$ & $\mathrm{M}$ & $\mathrm{SD}$ \\
\hline It helps students understand the lesson & 6 & 12 & 2.86 & 0.356 \\
$\begin{array}{l}\text { It attracts students, encouraging engagement in } 4 \\
\text { the lesson }\end{array}$ & 8 & & \\
It increases students' involvement & 4 & 8 & & \\
It facilitates the delivery of information & 3 & 6 & \\
It gives equal opportunities for learning & 2 & 4 & \\
It saves teachers' effort in the class & 2 & 4 &
\end{tabular}

In response to this question, teachers explained that they used BL because it helps students understand the lesson (12\%), encourages students' engagement in the lesson (8\%), increases 


\section{Macrothink}

their involvement $(8 \%)$, facilitates the delivery of information $(6 \%)$, gives equal learning opportunities (4\%), and saves teachers' effort during class $(4 \%)$. This result is attributed to EFL teachers' awareness of the benefits of BL and to the positive attitudes they have towards it. Teachers are also aware of the importance of ensuring that students are engaged and captivated during class

\subsection{Information and Communication Technology}

Table 7. Type of information and communication technology

\begin{tabular}{lcccc}
\hline Technology & $\mathrm{n}$ & $\%$ & $\mathrm{M}$ & $\mathrm{SD}$ \\
\hline Multimedia (Audio-Video) & 50 & 100 & 2.61 & 1.40 \\
$\begin{array}{l}\text { Projector/Laptop/Multimedia } \\
\text { application (PowerPoint) }\end{array}$ & presentation47 & 94 & & \\
Interactive Whiteboard & 30 & 60 & & \\
Computer Games & 27 & 54 & & \\
Educational Software & 25 & 50 & & \\
\hline
\end{tabular}

All of the participants reported that they use multimedia, (i.e., audio and video); $94 \%$ teachers stated that they use projector-laptop-multimedia presentation applications; $60 \%$ stated that they use interactive white boards; $54 \%$ indicated they use computer games; and 50\% answered that they use educational software. None of them used language learning websites, course web page, search engine or mobile applications (Table 7). Such findings have attributed to the growing awareness of using technology in teaching EFL. They make use of resources to provide necessary tools. Lack of resources is not an issue for some teachers. However, most others find the lack of infrastructure and knowhow as challenges.

Teacher 4 stated 'I like to use search engines but I do not have easy access to the Internet in my classes and there are no computers or labs for students' and 'We need training in designing and implementing BL activities effectively.'

These results are partially consistent with previous studies, such as Siew-Eng and Muuks (2015) have carried out a study, in which the effectiveness of different tools has been discussed. The study has mentioned that English teachers usually use PowerPoint, video clips, and laptops in their teaching. Allen, et al. (2013) further supported the outcomes that the digital projector and interactive whiteboard were commonly used tools in the academic settings. 
Table 8. Factors that can facilitate the implementation of BL

\begin{tabular}{|c|c|c|c|c|}
\hline Teacher's Needs & $\mathrm{n}$ & $\%$ & $\mathrm{M}$ & SD \\
\hline Training & 41 & 82 & 4.51 & 3.660 \\
\hline Internet Access & 35 & 70 & & \\
\hline English Language Lab & 26 & 52 & & \\
\hline Longer Classes & 26 & 52 & & \\
\hline More Knowledge about BL Strategies & 17 & 34 & & \\
\hline Well-equipped Classrooms (with technology) & 11 & 22 & & \\
\hline Electronic Curriculum & 10 & 20 & & \\
\hline Technical Support & 7 & 14 & & \\
\hline $\begin{array}{l}\text { Improvement in Teachers' Technological } \\
\text { Skills }\end{array}$ & 6 & 12 & & \\
\hline More Educational Software & 6 & 12 & & \\
\hline Small Class Sizes & 4 & 8 & & \\
\hline Educational Software & 3 & 6 & & \\
\hline $\begin{array}{l}\text { More Freedom to Apply Different Teaching } \\
\text { Methods }\end{array}$ & 3 & 6 & & \\
\hline Model Lessons conducted by Language & 2 & 4 & & \\
\hline Reduced Teaching Workload & 2 & 4 & & \\
\hline Modeling of Technology-enhanced Lessons & 1 & 2 & & \\
\hline
\end{tabular}

Table 8 provided complete details about such factors, in which $82 \%$ of teachers answered that they need training. This result refers to the shortage of BL training session being provided for EFL teachers in Saudi secondary schools in Tabuk as well as to the general lack of internet access in classes as some teachers clarifies in their responses.

Teacher 5 highlighted 'We need training in BL to understand how we can design (online and face-to-face) activities and implement them in the classroom effectively'.

Teacher 6 said that 'We need training in technological skills for using the new technologies as well as in integrating these technologies into teaching effectively'. Half of teachers need English language labs and more time to spend in the classroom. English language labs are needed especially to practice listening skills as teacher 7 said 'Most of the students in Saudi Arabia suffer from weak listening skills'. 


\section{Macrothink}

This result can be attributed to the lack of English language labs in secondary schools. Teachers also need more time to spend in the classroom to implement online and face -to-face activities, as teacher 8 stated that 'We need more time to spend in the classroom to help students practice all the language skills at the same time'. However, few teachers express the need for classrooms that are well-equipped with technology such as internet network, projector, and interactive whiteboard. They mainly stated that they need reliable Internet access as well as laptops for themselves and their students inside EFL classes. This result showed an overall lack of technological resources in purpose built school buildings as well as some newly developed ones, as teacher 9 in a rented school building said: 'Every day I bring my own laptop and my projector and the time of the class is wasted in operating my projector'. In addition, (20\%) of the teachers need electronic material so as to enable them to implement BL easily, and about (14\%) of participants need technical support, as teacher 10 stated 'There is an interactive whiteboard in the class but it does not work so we need ongoing maintenance for ICT tools'. $12 \%$ of teachers need to improve their technological skills and need more educational software. This result is attributed to the lack of maintenance and to the lack of technical support. In addition, $8 \%$ of teachers find that smaller numbers of students encourage teachers to implement BL in the classroom because crowded classrooms hinder them to blend methods successfully. $6 \%$ of the teachers needed more freedom in applying different methods in teaching. This result is attributed to interference of administrators and supervisors in the methods of teaching.

Table 9. Use of technology in teaching

\begin{tabular}{lllll}
\hline $\begin{array}{l}\text { Frequency of using } \\
\text { Technology }\end{array}$ & $\mathrm{n}$ & $\%$ & $\mathrm{M}$ & $\mathrm{SD}$ \\
\hline 1-2 times per Semester & 1 & 2 & 6.04 & 1.124 \\
3-4 times per Month & 2 & 4 & & \\
1-2 times per Week & 14 & 28 & \\
3-4 times per Week & 9 & 18 & \\
Daily & 24 & 48 & \\
Total & 50 & 100 & \\
\hline
\end{tabular}

In response to this question, most teachers reported using blended methods daily $(48 \%)$, followed by once or twice a week (28\%), followed by three to four times a week (18\%). A few teachers used BL three to four times per month (4\%), and only $2 \%$ reported using BL once or twice a semester. This result reflected the increasing awareness of the usefulness of BL among EFL teachers, their positive attitudes towards BL, and the widespread use of at 
least some technology in language classrooms.

The final interview question comprises four questions in a forced-choice format (yes/no) attempts to assess the existing infrastructure from the teacher's perspective.

Table 10. Existing infrastructure from the teacher's perspective

\begin{tabular}{lcccc}
\hline Question & Yes & No & M & SD \\
\hline & $\mathrm{N}(\%)$ & & & \\
Is there internet access in your classrooms? & $5(10 \%)$ & $45(90 \%)$ & 1.90 & 0.303 \\
Are your classrooms equipped with technology? & $28(56 \%)$ & $22(44 \%)$ & 1.44 & 0.501 \\
$\begin{array}{l}\text { Is the multimedia-resources room equipped with41 (82\%) } \\
\text { technology? }\end{array}$ & $9(18 \%)$ & 1.18 & 0.388 \\
$\begin{array}{l}\text { Do you have efficient technical support in your15(30\%) } \\
\text { school? }\end{array}$ & $35(70 \%)$ & 1.70 & 0.463 \\
\hline
\end{tabular}

In response to this question, 90\% reported that no Internet access is available in their classrooms. About 56\% reported that their classrooms are equipped with some technology. The majority of classrooms in most public Tatweer schools are equipped with technology such as interactive white boards and projectors, while other public schools are not, explaining the participants negative response about technology in classrooms (44\%). Moreover, most rented buildings do not have classrooms equipped with technology. In addition, $82 \%$ of teachers had access to a well-equipped multimedia-resources room. Similarly, most public Tatweer schools have such provisions, while only few rented schools have fully equipped multimedia resources rooms. However, $70 \%$ stated that they did not have efficient technical support in their schools suggesting a considerable lack of technical support and infrastructure in schools (Table10).

A study conducted on the Saudi female undergraduate students revealed that blended learning has the capability to offer successful learning experience in Saudi Arabia. It offers flexibility to the female students that help them in continuing with their higher education along with maintaining their tradition and cultural values (Alebaikan \& Troudi, 2010). Another study revealed that students who were taught using blended learning techniques scored good grades (Schwankl, 2013). Liu (2013) was successful in evaluating blended learning in terms of material development, grading, course design, student evaluation, and teacher reflection. The results showed that blended learning increased the student-student and student-teacher interactions. Blended learning is successful in eliminating communication anxiety among the students. Moreover, Alfahadi et al. (2015) indicated that teachers were positive towards blended learning. They were optimistic about how blended learning would help them to 
improve their performance and motivate the students.

\section{Conclusion}

In accordance with the objectives, majority of EFL teachers have supported the concept to prefer blending face-to-face and online instruction methods. However, the teachers have also indicated that there are no real BL practices used by them. There were some motivational factors for using BL, including ease of information delivery, attractiveness to students, effort-saving potential. At the same time, EFL teachers also mentioned that integration of ICT was a common practice in their teaching routine. The teachers have also reported during the interviews that a number of approaches should be developed for the integration of BL effectively. Such approaches mainly include training, better Internet access, classrooms well-equipped with technology, electronic material, technical support, better technological skills, more educational software, access to model lessons provided by language experts, reduced workload, better administrative support, and encouragement. More comprehensive studies are required to assess differential perspectives of teachers about EFL secondary teaching practices in blending learning.

\section{Recommendations}

In light of the study results, the researcher recommended the following:

1) The Ministry Of Education should provide schools with a clear policy on BL and create a suitable technologically equipped environment that facilitates new educational technologies in schools.

2) The ministry of education should provide access to technicians in all schools to help teachers when required.

3) Supervisors should train EFL teachers to use BL strategy into their teaching practices.

4) Administrators should motivate EFL teachers to attend BL professional development programs for teaching methods and pedagogy.

\section{Limitation}

The results of the present study were confined to a specific area (Tabuk city) and it was difficult to generalize the results concerning the entire population.

\section{References}

Aguilar, M., \& Alexandra, J. (2012). Blended learning and the language teacher: A literature review. Colombian Applied Linguistics, 14(2), 163-180. https://doi.org/10.14483/udistrital.jour.calj.2012.2.a10

Alammary, A., Sheard, J., \& Carbone, A. (2014). Blended learning in higher education: Three different design approaches. Australasian Journal of Educational Technology, 30(4). https://doi.org/10.14742/ajet.693

Alebaikan, R., \& Troudi, S. (2010). Blended learning in Saudi universities: challenges and 
perspectives. ALT-J, 18(1), 49-59. https://doi.org/10.1080/09687761003657614

Alebaikan, R., \& Troudi, S. (2010). Blended learning in Saudi universities: challenges and perspectives. ALT-J, 18(1), 49-59. https://doi.org/10.1080/09687761003657614

Alfahadi, A. M., Alsalhi, A. A., \& Alshammari, A. S. (2015). EFL secondary school teachers' views on blended learning in Tabuk city. English Language Teaching, 8(9), 51. https://doi.org/10.5539/elt.v8n9p51

Allan, B. (2007). Blended learning: Tools for teaching and training. Facet Publishing.

Allen, T. T., Artis, S., Afful-Dadzie, A., \& Allam, Y. (2013). Case study application of blended learning for an engineering simulation course.

Al - Qahtani, A. A., \& Higgins, S. E. (2013). Effects of traditional, blended and e - learning on students' achievement in higher education. Journal of Computer Assisted Learning, 29(3), 220-234. https://doi.org/10.1111/j.1365-2729.2012.00490.x

Asiri, M. J. S., bt Mahmud, R., Bakar, K. A., \& bin Mohd Ayub, A. F. (2012). Factors influencing the use of learning management system in Saudi Arabian higher education: A theoretical framework. Higher Education Studies, 2(2), 125. https://doi.org/10.5539/hes.v2n2p125

Bernard, R. M., Borokhovski, E., Schmid, R. F., Tamim, R. M., \& Abrami, P. C. (2014). A meta-analysis of blended learning and technology use in higher education: from the general to the applied. Journal of Computing in Higher Education, 26(1), 87-122. https://doi.org/10.1007/s12528-013-9077-3

Bishop, J. L., \& Veliger, M. A. (2013, June). The flipped classroom: A survey of the research. In ASEE National Conference Proceedings, Atlanta, GA (Vol. 30, No. 9, pp. 1-18).

Comas-Quinn, A. (2011). Learning to teach online or learning to become an online teacher: An exploration of teachers' experiences in a blended learning course. ReCALL, 23(03), 218-232. https://doi.org/10.1017/S0958344011000152

Ellis, R. A., Steed, A. F., \& Applebee, A. C. (2006). Teacher conceptions of blended learning, blended teaching and associations with approaches to design. Australasian Journal of Educational Technology, 22(3). https://doi.org/10.14742/ajet.1289

Finn, A., \& Bucceri, M. (2004). A case study approach to blended learning. Los Angeles: Centra Software. Retrieved March, 23, 2008.

Graham, C. R. (2006). Blended learning systems. The handbook of blended learning, 3-21.

Grgurovic, M. (2010). Technology-enhanced blended language learning in an ESL class: A description of a model and an application of the diffusion of Innovations theory.

Higgins, D., \& Gomez, A. (2014). Teaching English studies through blended learning. The Higher Education Academy, England.

Holmes, B., \& Gardner, J. (2006). E-learning: Concepts and practice. Sage. 
Ibrahim, A. H., \& Yusoff, Z. S. (2012). Teaching public speaking in a blended learning environment. International Journal of Social Science and Humanity, 2(6), 573.

Joshi, A. (2012). Multimedia: A Technique in Teaching Process in the Classrooms. Current World Environment, 7(1), 33-36.

Kruger, J., \& Dunning, D. (1999). Unskilled and unaware of it: how difficulties in recognizing one's own incompetence lead to inflated self-assessments. Journal of personality and social psychology, 77(6), 1121. https://doi.org/10.1037/0022-3514.77.6.1121

Liu, M. (2013). Blended Learning in a University EFL Writing Course: Description and Evaluation. Journal of Language Teaching \& Research, 4(2). https://doi.org/10.4304/j1tr.4.2.301-309

López-Pérez, M. V., Pérez-López, M. C., \& Rodríguez-Ariza, L. (2011). Blended learning in higher education: Students' perceptions and their relation to outcomes. Computers \& Education, 56(3), 818-826. https://doi.org/10.1016/j.compedu.2010.10.023

Mason, R., \& Rennie, F. (2006). Elearning: The key concepts. Routledge.

Means, B., Toyama, Y., Murphy, R. O. B. E. R. T., \& Baki, M. (2013). The effectiveness of online and blended learning: A meta-analysis of the empirical literature. Teachers College Record, 115(3), 1-47.

Neumeier, P. (2005). A closer look at blen ded learning - parameters for designing a blended learning environment for language teaching and learning. ReCALL, 17(02), 163-178. https://doi.org/10.1017/S0958344005000224

Plano Clark, V. L., Anderson, N., Wertz, J. A., Zhou, Y., Schumacher, K., \& Miaskowski, C. (2015). Conceptualizing longitudinal mixed methods designs: a methodological review of health sciences research. Journal of Mixed Methods Research, 9(4), 297-319. https://doi.org/10.1177/1558689814543563

Poon, J. (2013). Blended learning: An institutional approach for enhancing students' learning experiences. Journal of online learning and teaching, 9(2), 271.

Schwankl, E. R. (2013). Blended Learning: Achievement and Perception (Doctoral dissertation, Master Dissertation, Southwest Minnesota State University).

Siew-Eng, L., \& Muuk, M. A. (2015). Blended learning in teaching secondary schools' English: A preparation for tertiary Science education in Malaysia. Procedia-Social and Behavioral Sciences, 167, 293-300. https://doi.org/10.1016/j.sbspro.2014.12.677

Tayebinik, M., \& Puteh, M. (2013). Blended Learning or E-learning?

\section{Copyright Disclaimer}

Copyright reserved by the author(s).

This article is an open-access article distributed under the terms and conditions of the Creative Commons Attribution license (http://creativecommons.org/licenses/by/3.0/). 